\title{
Prolactin in Ovarian Follicular Fluid Stimulates Endothelial Cell Proliferation
}

\author{
Alejandra Castilla Celina García Martha Cruz-Soto \\ Gonzalo Martínez de la Escalera Stéphanie Thebault Carmen Clapp \\ Instituto de Neurobiología, Universidad Nacional Autónoma de México, Querétaro, México
}

\section{Key Words}

Vascular endothelium • Endothelial cell proliferation • Angiogenesis $\cdot$ Prolactin receptor $\cdot$ Ovarian follicle $\cdot$ Follicular fluid

\begin{abstract}
Angiogenesis is essential for the growth and maturation of the ovarian follicle and its transition into the corpus luteum. In addition to the main proangiogenic factors, vascular endothelial growth factor (VEGF) and basic fibroblast growth factor (bFGF), follicular fluid (FF) contains the hormone prolactin (PRL), which is known to promote angiogenesis in vivo. Here, we show that FF from large follicles, which contains twice the PRL level of FF from small follicles, stimulates endothelial cell proliferation to a greater extent than the latter, and that immunoneutralization of PRL prevents FF from stimulating endothelial cell proliferation. Notably, the FF increases the expression of the short and long PRL receptor isoforms in endothelial cells, and a purified PRL standard stimulates endothelial cell proliferation but only after the cells have been pretreated with FF. However, purified PRL activates the JAK2/STAT3 pathway in endothelial cells in the absence of pretreatment with FF. In summary, PRL present in the FF stimulates the proliferation of endothelial cells. This effect likely involves the upregulation of the short and long $P R L$ receptor isoforms and is independent of PRL-induced JAK2/STAT3 signaling.

Copyright $\odot 2009$ S. Karger AG, Basel
\end{abstract}

\section{Introduction}

The cyclic growth and maturation of the ovarian follicle represents a unique physiological example of rapid expansion supported by angiogenesis, which is followed by angioregression during luteolysis [1]. Increased follicle vasculature within the theca cell layer is largely responsible for folliculogenesis, and new blood vessels, which are particularly permeable, favor antrum formation and eventual follicle rupture. After ovulation, massive angiogenesis supports follicle transformation into the corpus luteum [1]. The follicular fluid (FF) contains pro- and antiangiogenic factors such as vascular endothelial growth factor (VEGF) [1], basic fibroblast growth factor (bFGF) [2], angiopoietin 1 and 2 [3], and thrombospondin [4]. Several studies clearly show an essential role for VEGF in follicular angiogenesis [5]; however, the contribution of other proangiogenic factors in FF has not been fully established.

Prolactin (PRL), a hormone known to regulate numerous physiological processes including angiogenesis [6], is also present in FF [7]. The angiogenic properties of PRL vary depending upon its molecular structure. Vasoinhibins, which are proteolytic fragments of the full-length 23$\mathrm{kDa}$ protein [8], and a phosphorylated $23-\mathrm{kDa}$ PRL iso-

\section{A.C. and C.G. contributed equally to this study.}

\section{KARGER}

Fax +41613061234 E-Mail karger@karger.ch www.karger.com

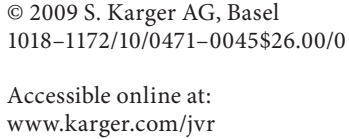

Dr. Stéphanie Thebault

Instituto de Neurobiología, Universidad Nacional Autónoma de México

Campus UNAM-Juriquilla

Querétaro 76230 (México)

Tel. +52 442238 1029, Fax +52 442238 1005, E-Mail stephaniethebault@gmail.com 
form [9] exert inhibitory actions on blood vessels. In contrast, several studies have shown that the unmodified $23-\mathrm{kDa}$ PRL can promote angiogenesis [see review in ref. 6]. Treatment with PRL induces endothelial cell proliferation in the corpora lutea of cycling rats, while reducing circulating PRL levels with bromocriptine [10] or deleting the PRL receptor in knockout mice [11] interferes with corpus luteum angiogenesis. Furthermore, PRL promotes angiogenesis in the chick embryo chorioallantoic membrane [12], in the testis [13] and in the myocardium [14]. However, the direct effect of PRL on endothelial cells remains debatable, because most studies $[6,8,9,12,15]$, except for one [16], failed to show any effect of PRL on the proliferation of endothelial cells in culture. Nevertheless, the PRL receptor, which belongs to the PRL-growth hormone-cytokine receptor superfamily and activates the JAK/STAT signaling pathway [17], exists in endothelial cells as short and/or long isoforms $[9,15,18]$.

The objective of this study was to investigate whether PRL present in FF has proangiogenic effects. Accordingly, we determined PRL levels in FF and assayed the effect of FF on endothelial cell proliferation following PRL immunodepletion. Also, the presence of PRL receptors and the activation of the JAK2/STAT3 signaling pathway were evaluated in endothelial cells treated with FF and PRL.

\section{Materials and Methods}

\section{Reagents}

Bovine PRL (BIO grade) and bovine PRL antiserum (RIA grade, National Hormone and Pituitary Program, NHPP 2) were obtained from the NHPP, Torrance, Calif., USA. Antiserum was also raised locally in rabbits by immunization with NHPP bovine 23K PRL (NHPP 1). Anti-bovine PRL monoclonal antibodies, 5G2 and 6F11, were kindly provided by Jonathan Scammel (University of South Alabama, Mobile, Ala., USA). Control antibodies were purified from normal rabbit serum (NRS), and purified nonimmune mouse antibodies were from ICN Biomedicals (Aurora, Ill., USA). AntiPRL receptor polyclonal R116 and monoclonal U5 antibodies were kind gifts from Li-Yuan Yu-Lee (Houston, Tex., USA) and Paul Kelly (INSERM U584, Paris, France), respectively. Human bFGF was generously donated by Judith Abraham (Scios, Mountain View, Calif., USA). The JAK2 inhibitor, AG490, was purchased from Calbiochem (Cat. No. 658401, San Diego, Calif., USA).

\section{Follicular Fluid}

Ovaries and serum were obtained from healthy cows (state slaughterhouse, $\mathrm{n}=90$ ). After sacrifice, ovaries were conserved in saline solution $(0.9 \% \mathrm{NaCl})$ at $4{ }^{\circ} \mathrm{C}$. FF was extracted by direct puncture of the follicles and was pooled in 2 different groups (small, $\leq 5 \mathrm{~mm}$, and large, $\geq 10 \mathrm{~mm}$ diameter). The diameter of follicles was measured on the surface of ovaries by a Vernier meter. FF from small follicles (about $5 \mu$ l per follicle) was punctured using an insulin syringe and pooled from about 15 small follicles. FF pools were centrifuged at $400 \mathrm{~g}$ for $10 \mathrm{~min}$, and supernatants were stored at $-20^{\circ} \mathrm{C}$.

\section{Nb2 Cell Bioassay}

Bioactive PRL was determined using the Nb2 cell bioassay, as detailed previously [19]. Briefly, incubations were carried out for $48 \mathrm{~h}$ in the absence or presence of $10 \mu \mathrm{l}$ of FF from small or large follicles, or of the bovine PRL standard with or without a $1 / 500$ dilution of the NHPP 1 anti-PRL antiserum. Nb2 cell proliferation was measured by the 3-[4,5-dimethylthiazol-2-yl]-2,5-diphenyltetrazolium bromide (MTT) method, as described below.

\section{ELISA}

The assay was performed as previously reported [20] using wells coated with $10 \mathrm{nM}$ bovine PRL, a $1 / 2,000$ dilution of the NHPP 2 anti-bovine PRL antiserum, and a 1/2,000 dilution of horseradish peroxidase-conjugated second antibodies (Vector Laboratories, Burlingame, Calif., USA). Bound horseradish peroxidase-conjugated antibodies were revealed by reaction with $o$ phenylenediamine dihydrochloride in the presence of hydrogen peroxide. Optical density was measured at $490 \mathrm{~nm}$.

\section{Bovine Umbilical Vein Endothelial Cell Culture}

Bovine umbilical vein endothelial cells (BUVECs), obtained and cultured as described [21], were incubated in 96-well plates in F12K medium (AppliChem GmbH, A1963) with 0.5\% FBS for $24 \mathrm{~h}$. Cells were subjected to a series of treatments (all in $100 \mu \mathrm{l}$ of complete $10 \%$ FBS culture medium) that include a 48 -hour incubation with $0.5,1,2.5,5$ and $10 \mu \mathrm{l}$ of FF from small and large follicles that correspond to FF dilution ratios of 1/200, 1/100, 1/40, $1 / 20$ and $1 / 10$, respectively. Incubations with FF were or were not combined with anti-PRL antibodies. Negative controls included control antibodies and aliquots of $\mathrm{FF}$ from large follicles that were inactivated by incubation for $30 \mathrm{~min}$ at $90^{\circ} \mathrm{C}$, followed by centrifugation for $60 \mathrm{~min}$ at $2,500 \mathrm{~g}$ to remove denatured proteins. In other experiments, BUVECs were or were not treated with increasing doses of PRL alone $(0.02,0.1,0.2,1,2$ and $10 \mathrm{nM})$ for $36 \mathrm{~h}$, after a preincubation period of $12 \mathrm{~h}$ with or without a $1 / 10$ dilution of FF from large follicles. In addition, some cultures were treated for 15 min with the JAK2 inhibitor AG490 (100 $\mu \mathrm{M})$ [22] before a 12-hour incubation with or without FF followed by a 36hour incubation in the absence or presence of $2 \mathrm{nM}$ PRL.

\section{Cell Proliferation Assay}

Cell proliferation was assessed by reduction of MTT, as previously described [23]. Briefly, cells were incubated with MTT (500 $\mathrm{mg} / \mathrm{ml}$, CGD1, Sigma-Aldrich, St. Louis, Mo., USA) at $37^{\circ} \mathrm{C}$ for $4 \mathrm{~h}$, and the formazan precipitate was solubilized with $0.4 \mathrm{~N} \mathrm{HCl}$ $10 \%$ SDS for $30 \mathrm{~min}$ at room temperature and quantified by measuring absorbance at $570 \mathrm{~nm}$. This colorimetric assay has been validated as an index of cell proliferation [23]

\section{Western Blot Analysis}

One microgram of total proteins from FF of small or large follicles was subjected to reducing SDS gel electrophoresis using $15 \%$ polyacrylamide, blotted onto nitrocellulose, probed with anti-PRL antisera (NHPP 1, 1/500 dilution; NHPP 2, 1/300 dilution) or NRS (1/300 dilution), and developed using the alkaline phosphatase second antibody kit (Bio-Rad Laboratories, Hercu- 
les, Calif., USA). To analyze the PRL receptor, samples containing $60 \mu \mathrm{g}$ of BUVEC homogenate protein were boiled in reducing buffer and separated on $7.5 \%$ polyacrylamide gels; the Western blots were probed with a $1 / 500$ dilution of polyclonal R116, of monoclonal U5 anti-PRL receptor, or of polyclonal anti-actin (sc7210, Santa Cruz Biotechnology, Santa Cruz, Calif., USA) antibodies and revealed using an alkaline phosphatase-coupled secondary antibody and colorimetric detection kit (Bio-Rad Laboratories), or with horseradish peroxidase-coupled secondary antibodies (111-035-003, Jackson Immunoresearch Laboratories Inc., West Grove, Pa., USA) and enhanced chemiluminescence (ECL, SuperSignal West Pico Chemiluminescent Substrate, Pierce Biotechnology, Rockford, Ill., USA). Similarly, to analyze signaling molecules, BUVECs pretreated or not pretreated with FF from large follicles for 12, 24 or $48 \mathrm{~h}$ after $24 \mathrm{~h}$ of serum starvation were incubated 5 min with or without PRL, washed with PBS, lysed in lysis buffer (5 mM Tris- $\mathrm{HCl}, \mathrm{pH} 7.4,100 \mathrm{mM} \mathrm{NaCl}$, 0.5\% Nonidet, $1 \mathrm{~mm}$ EGTA, $10 \mu \mathrm{g} / \mathrm{ml}$ aprotinin, $1 \mathrm{mM}$ PMSF), centrifuged at $12,000 \mathrm{~g}$ for $10 \mathrm{~min}$ at $4^{\circ} \mathrm{C}$ and processed by Western blot. BUVEC protein samples were probed with monoclonal anti-phosphotyrosine (p-Tyr, clone 4610, 1/200 dilution, Upstate-Millipore, Billerica, Mass., USA) antibody, revealed using horseradish peroxidase-coupled secondary antibodies and enhanced chemiluminescence; membranes were then stripped and reprobed with polyclonal anti-total STAT-3 (sc-483, 1/250 dilution, Santa Cruz Biotechnology) or polyclonal anti-total JAK2 (No. 06-255, 1/1,000 dilution, Upstate-Millipore) antibodies and revealed using the alkaline phosphatase secondary antibody kit. Optical density values were determined using the 1D image analysis software version 3.5 (Eastman Kodak Company, Rochester, N.Y., USA).

\section{Statistical Analysis}

Statistical significance was determined by analysis of variance (ANOVA) followed by the unpaired Student's t test with the Sigma Stat 7.0 software (Systat Software Inc., San Jose, Calif., USA); the significance level was set at $\mathrm{p}<0.05$.

\section{Results}

\section{FF Contains PRL and Exerts a Mitogenic Effect on}

Endothelial Cells

FF stimulated the proliferation of BUVECs (fig. 1b). The mitogenic effect of FF from large follicles reached significantly higher values than that of FF from small follicles. At dilutions of $1 / 40$ to $1 / 10$, the effect of FF from large follicles was similar to that induced by $0.25 \mathrm{~nm}$ $\mathrm{bFGF}$, one of the main proangiogenic factors present in FF [24] (fig. 1b). The effect of FF from large follicles was eliminated by heat inactivation (fig. 1b), indicating that thermosensitive protein(s) mediate this action. Western blots showed that $23-\mathrm{kDa}$ PRL was present in FF and indicated that its level increased with follicular size (fig. 1c). Immunostain specificity was confirmed by 2 polyclonal anti-PRL antisera and the lack of reaction with NRS. PRL concentrations in FF measured by ELISA and the $\mathrm{Nb} 2$ lymphoma bioassay (fig. 1d) were similar and confirmed the observation by Western blot of higher PRL levels in large versus small follicles. All subsequent experiments were conducted with FF from large follicles.

\section{PRL in FF Stimulates Endothelial Cell Proliferation}

To assess the direct involvement of endogenous PRL in the mitogenic effect of FF, BUVEC proliferation in response to FF was tested in the presence of anti-PRL antisera, monoclonal anti-PRL antibodies, NRS or control mouse IgGs. All 4 anti-PRL antibodies reversed the mitogenic effect of FF on BUVECs to control levels, while preimmune sera or IgGs did not (fig. 2c). Treatment with the NHPP 1 anti-PRL antiserum alone (fig. $2 c$ ) had no effect on BUVEC proliferation.

To further examine the effect of PRL, BUVECs were incubated with a purified PRL standard during the last $36 \mathrm{~h}$ of a 48 -hour incubation period. PRL did not affect BUVEC proliferation at any of the concentrations tested (0.02-10 nM) (fig. 2d). To evaluate whether FF was required for PRL to stimulate endothelial cell proliferation, BUVECs were pretreated for $12 \mathrm{~h}$ with FF (1/10 dilution) and then incubated in the absence of FF with or without the PRL standard for the remaining $36 \mathrm{~h}$. Treatment with FF for $12 \mathrm{~h}$ in the absence of PRL had no effect on BUVEC proliferation. However, after a 12-hour preincubation with FF, all concentrations of PRL significantly enhanced endothelial cell proliferation (fig. 2d).

\section{FF Upregulates the Long and the Short PRL \\ Receptor Isoforms, and PRL and FF Stimulate the \\ Phosphorylation of JAK2 and STAT3}

To elucidate the molecular mechanisms of PRL action in BUVEC, the effect of FF on the expression of the short and long PRL receptors was investigated. Both a monoclonal antibody (U5) and a polyclonal (R116) anti-PRL receptor antibody detected protein bands of apparent molecular weights of 65 and $34 \mathrm{kDa}$, which correspond to the expected size of the bovine long and short PRL receptor isoforms, respectively (fig. 3d). Compared with untreated conditions, FF (1/10 dilution) treatment for 12 , 24 and $48 \mathrm{~h}$ increased the intensity of both immunoreactive bands (fig. 3e).

Next, activation of JAK2 and STAT3 was evaluated in order to determine the functionality of PRL receptors in BUVECs. The incubation of BUVECs for $12 \mathrm{~h}$ with FF (1/10 dilution) stimulated JAK2 and STAT3 phosphorylation to levels 2.7 and 6.3 times those of the control, respectively (fig. 3f-h). A short-term exposure to PRL ( $2 \mathrm{nM}$ 


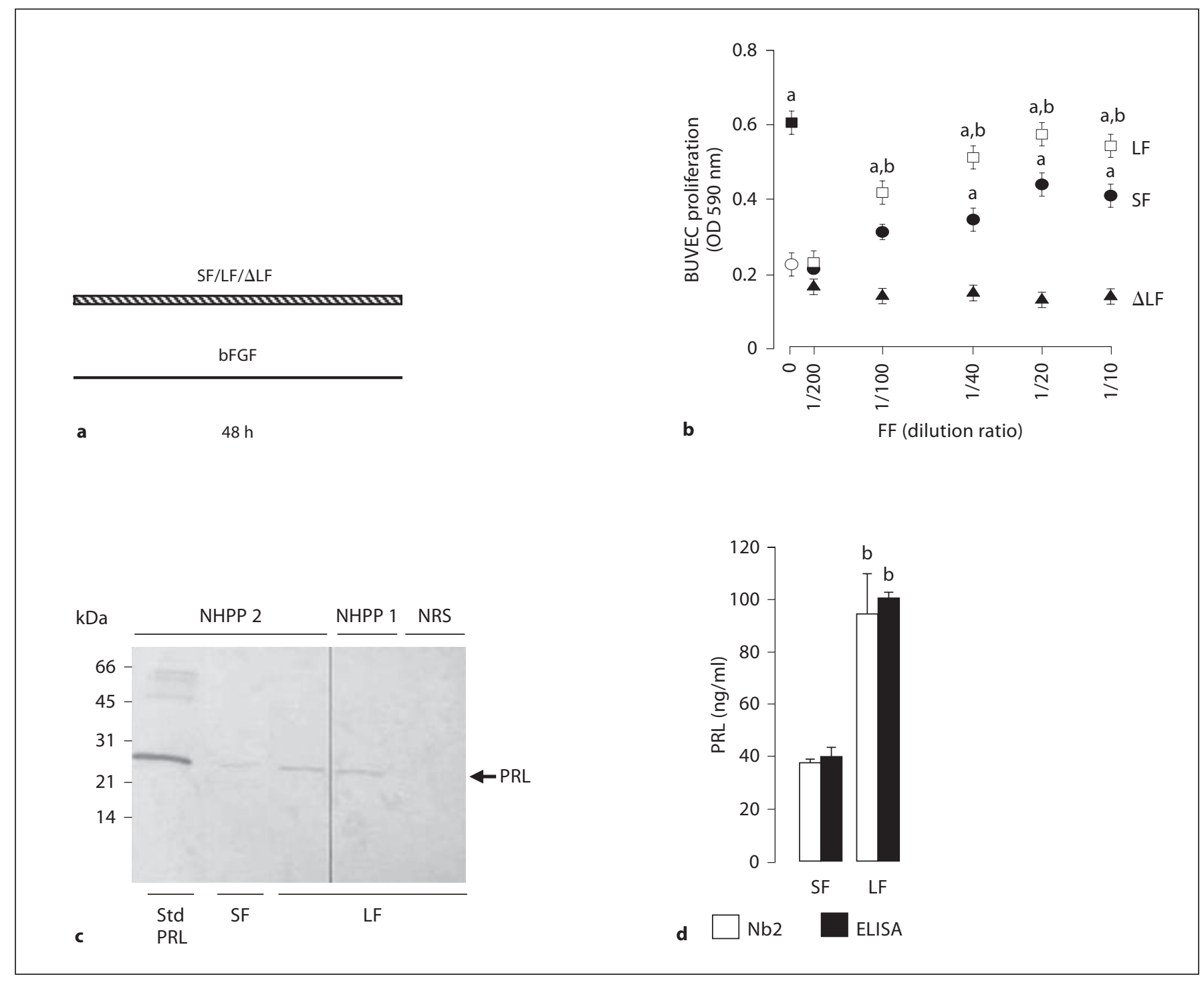

Fig. 1. a Line diagram depicting the different protocols used in experiments shown in $\mathbf{b}$. b Dose-dependent effect on BUVEC proliferation of a 48-hour treatment with dilution ratios of $1 / 200$, $1 / 100,1 / 40,1 / 20$ and $1 / 10$ of FF from small (SF) and large follicles $(\mathrm{LF})$ or heat-inactivated large follicles $(\Delta \mathrm{LF})$. As a positive control, BUVECs were incubated with bFGF $(0.25 \mathrm{nM})$ for $48 \mathrm{~h}(\boldsymbol{a}){ }^{\mathrm{a}} \mathrm{p}<$ 0.05 versus no treatment $(\bigcirc) ;{ }^{b} \mathrm{p}<0.05$ versus small follicles. c Representative Western blot analysis of PRL in FF from small

for $5 \mathrm{~min}$ ) also increased JAK2 and STAT3 phosphorylation by 5 - and 0.5 -fold compared with the controls (fig. 3f-h). Notably, when applied after FF, PRL did not further increase the effect of FF on JAK2; STAT3 phosphorylation was lower than that observed with FF alone but higher than that induced by exogenous PRL alone
(SF) and large follicles (LF) using polyclonal anti-PRL antisera (NHPP 1 and NHPP 2) or NRS ( $=3$ ). A standard of 23-kDa PRL (Std PRL) was used, and equal concentrations of total proteins were loaded. d PRL concentration (mean \pm SEM) in small (SF) and large follicles (LF) determined by the Nb2 lymphoma cell proliferation assay $(\mathrm{n}=3)$ and ELISA $(\mathrm{n}=3) .{ }^{\mathrm{b}} \mathrm{p}<0.05$ versus small follicles.

(fig. 3f-h). To analyze the contribution of a JAK2-dependent pathway to the mitogenic action of the FF on endothelium, BUVECs were preincubated with the JAK2 inhibitor AG490 [22] before treatment with FF and/or PRL. AG490 abrogated neither the promoting effect of FF alone nor that of PRL after incubation with FF (fig. 3i). 


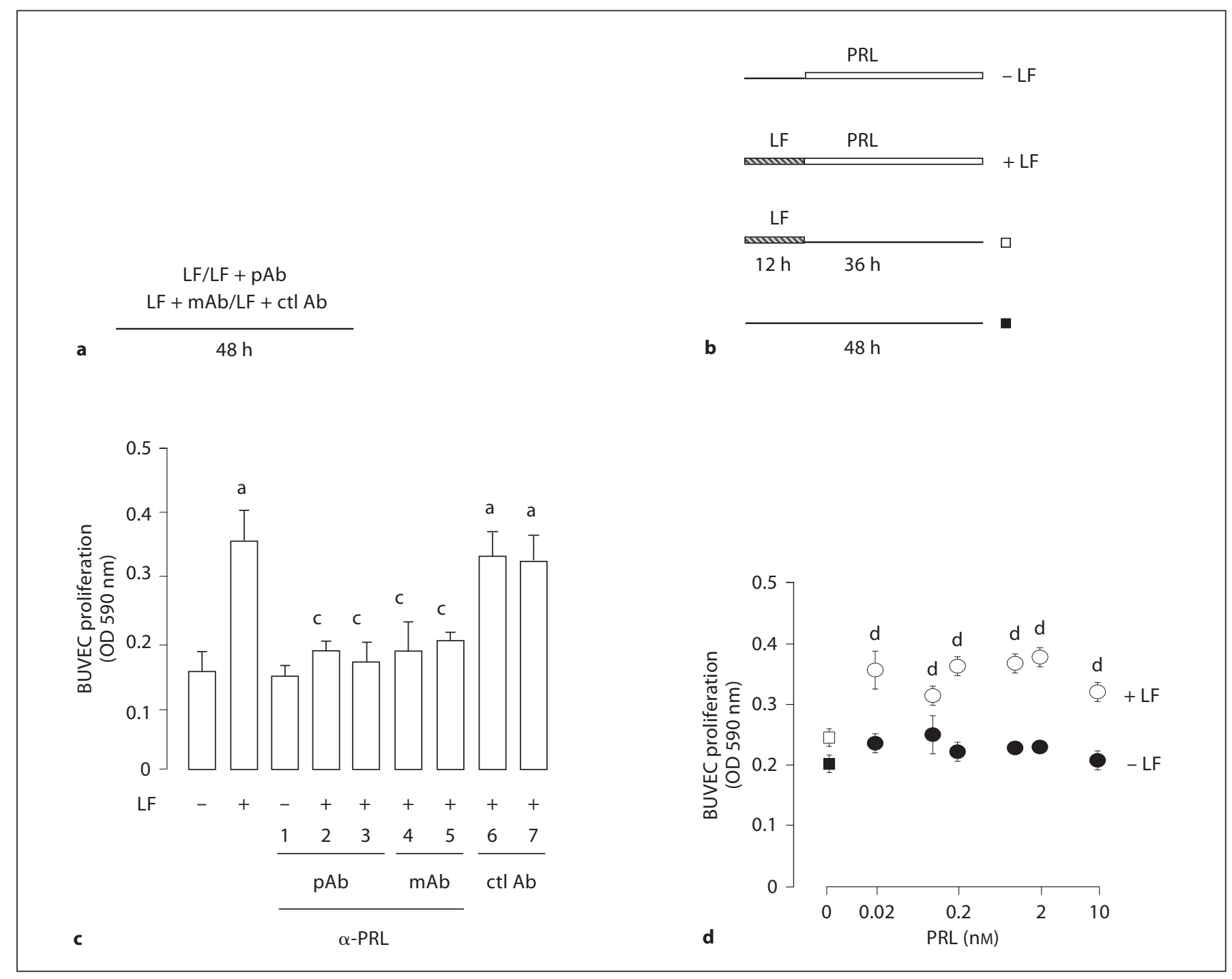

Fig. 2. a, b Line diagrams depicting the different protocols used in experiments shown in $\mathbf{c}$ and $\mathbf{d}$, respectively. $\mathrm{pAb}=$ Polyclonal anti-PRL antibody; $\mathrm{mAb}=$ monoclonal anti-PRL antibody; $\mathrm{ctl}$ $\mathrm{Ab}=$ control antibody. $\mathbf{c}$ Histogram summarizing the effect of FF from large follicles (LF) for $48 \mathrm{~h}$ (1/10 dilution) on BUVEC proliferation in the presence of polyclonal anti-PRL antibodies (pAb: column 2, NHPP 1; column 3, NHPP 2, 1:500 dilution), monoclonal anti-PRL antibodies (mAb: column 4, 5G2; column 5, 6F11, $1 \mu \mathrm{g} / \mathrm{ml}$ ), or control antibodies (ctl Ab: column 6, NRS, 1:500 dilution; column 7, mouse IgG, $2 \mu \mathrm{g} / \mathrm{ml}$ ). As a negative control, BUVECs were treated with only an anti-PRL polyclonal anti- body (column 1, NHPP 1). - and + indicate the absence or presence of large follicles (LF). ${ }^{\mathrm{a}} \mathrm{p}<0.05$ versus no treatment; ${ }^{\mathrm{c}} \mathrm{p}<$ 0.05 versus large follicles alone $(n=3)$. $\mathbf{d}$ Effect on BUVEC proliferation of PRL provided for $36 \mathrm{~h}$ after incubation periods of $12 \mathrm{~h}$ in the absence (- LF) or presence of large follicles (1/10 dilution, $+\mathrm{LF}$ ). In other BUVECs, preincubation for $12 \mathrm{~h}$ with large follicles was followed by a 36-hour incubation with control medium, i.e. devoid of PRL and large follicles ( $\square$ ), or the cells were incubated only in control medium for $48 \mathrm{~h}(\boldsymbol{\square}){ }^{\mathrm{d}} \mathrm{p}<0.05$ versus the corresponding concentration in PRL $(\mathrm{n}=3)$.

\section{Discussion}

Angiogenesis is required for the maturation of ovarian follicles [24], and FF contains various proangiogenic factors that originate in granulosa cells or derive from the circulation [24-26]. Here, we report that PRL present in FF stimulates endothelial cell proliferation, and that this action likely requires the upregulation of the long and the short PRL receptor isoforms and the cooperation of signaling molecules other than JAK2 and STAT3. These 


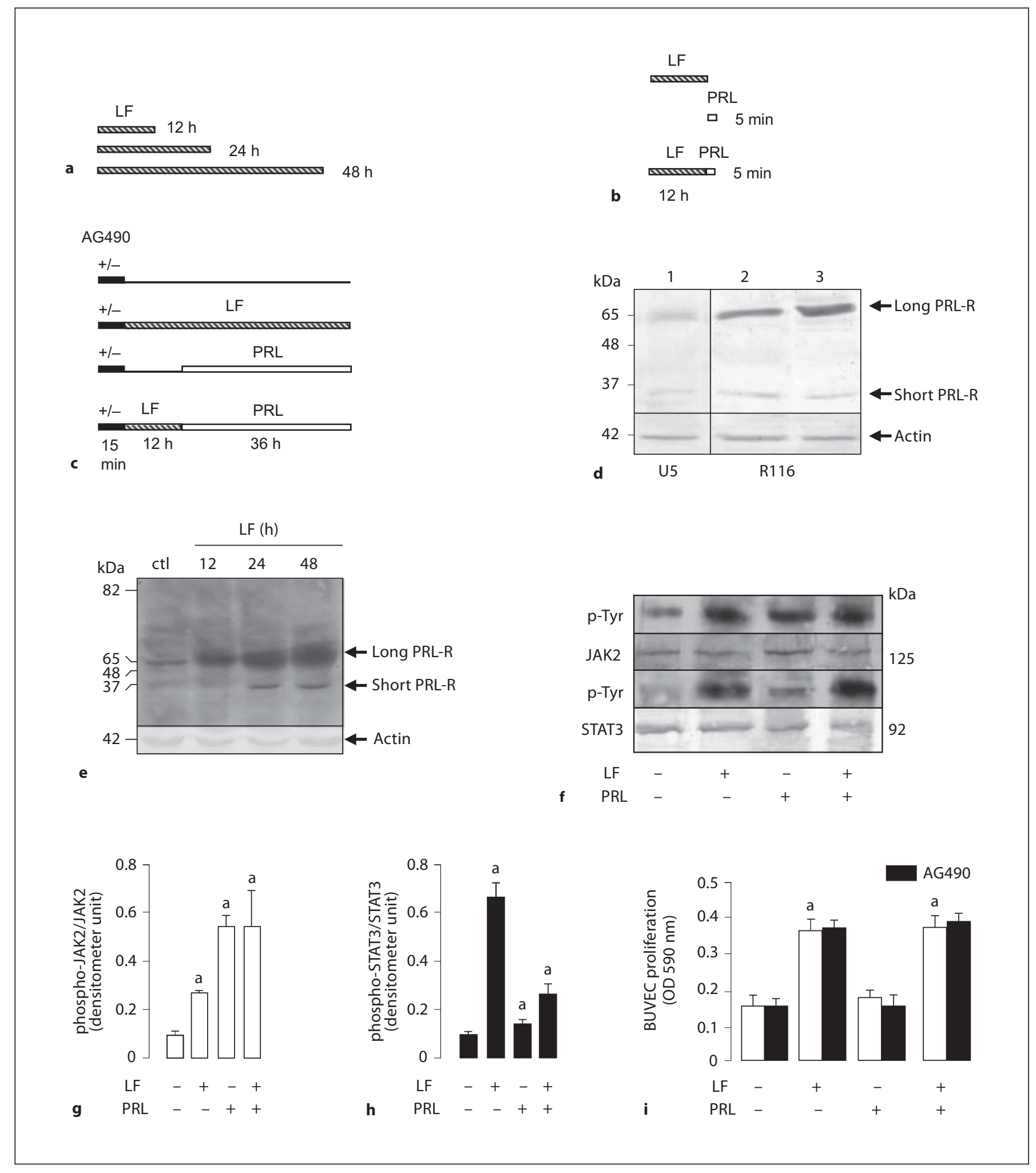


findings support the hypothesis that increasing levels of PRL during follicle development promote angiogenesis, and therefore, that the impact of PRL on folliculogenesis is broader than previously appreciated.

PRL is present in the FF of the human [7], porcine [27] and bovine [28] ovarian follicle and it can originate locally, since the PRL mRNA is expressed in human ovarian follicular cells [29] and PRL is present in granulosa cells of mature rat follicles [30]. The PRL levels measured in bovine $\mathrm{FF}$ were within the range reported for bovines $(20-80$ $\mathrm{ng} / \mathrm{ml})[31]$ and humans $(30-137 \mathrm{ng} / \mathrm{ml})[32,33]$. Furthermore, the PRL concentration was significantly higher in large than in small follicles [28], although it is unclear whether large follicles correspond to preovulatory or to atresic follicles. The facts that both ELISA and the bioassay measured equivalent PRL levels and that a $23-\mathrm{kDa}$ immunoreactive protein was observed by Western blot suggest that FF contains mainly unmodified $23-\mathrm{kDa}$ PRL, the PRL isoform against which both assays were calibrated.

The ability of FF to induce angiogenesis has been demonstrated previously in other mammalian species [34] and was mainly attributed to proangiogenic factors such as VEGF and bFGF [24]. However, not all the angiogenic activity of FF is due to these factors [35]. Here, we show that immunoneutralization of PRL blocks the ability of FF to promote endothelial cell proliferation, suggesting that PRL in FF is a major mitogenic factor for endothelial cells. However, it is hard to understand why PRL immunoneutralization removes all angiogenic activity of FF. While it is possible that PRL could be part of a major mitogenic complex with other proangiogenic factors, similar observations in other tissues indicate that immunoneutralization techniques do not exclude the action of other potent regulators of angiogenesis. For example, immunoneutralization of single antiangiogenic factors such as pigment epithelium-derived factor [36] or vasoinhibins [37] induces angiogenesis in ocular tissues, abrogating the inhibitory action of the molecule targeted by the antibody as well as that of the other antiangiogenic factors present in the eye. Notably, a higher concentration of PRL in the FF, as seen in FF from larger follicles by Western blot, ELISA and $\mathrm{Nb} 2$ bioassay, could be associated with a greater ability of FF to promote endothelial cell proliferation.

The proangiogenic effect of PRL is supported by studies reporting that angiogenesis during corpus luteum development is strongly inhibited in PRL receptor knockout mice [11] and that PRL increases endothelium proliferation in the corpus luteum [10]. However, the proangiogenic effect of PRL may depend on local circumstances. Most studies have failed to show a direct effect of PRL on the proliferation of cultured endothelial cells [6], presumably because PRL receptors are already occupied by PRL produced in endothelial cells themselves [6]. In our experiments, treatment with purified PRL did not stimulate the proliferation of cultured endothelial cells unless the cells were preincubated for $12 \mathrm{~h}$ with FF. In these conditions, the mitogenic effect of the PRL standard occurred at concentrations equivalent to those found in the FF of small (2 nM) and large (4 nM) follicles. We interpreted these findings to mean that FF contains a component, distinct from PRL, which can facilitate PRL action, perhaps by upregulating the expression of the PRL receptor.

Two different anti-PRL receptor antibodies detected proteins with apparent molecular weights of 65 and 34 $\mathrm{kDa}$ that probably correspond to the long and short PRL receptor isoforms identified previously in BUVECs [15]. Notably, we demonstrate that an incubation with the FF for 12, 24 or $48 \mathrm{~h}$ induces an increase in these PRL recep-
Fig. 3. a-c Line diagrams depicting the different protocols used in experiments shown in $\mathbf{d}-\mathbf{i}$. LF $=$ Large follicles. $\mathbf{d}$ BUVECs were incubated in the absence of FF and their lysates evaluated by Western blots using the anti-PRL receptor monoclonal U5 antibody (lane 1) and the polyclonal anti-PRL receptor R116 antibody (lane 2). The R116 was also used in lysates from bovine aortic endothelial cells (lane 3). Actin served as loading control. PRL-R = PRL receptor. e Western blot analysis with the R116 antibody of lysates from BUVECs treated or not treated (ctl) with FF from large follicles (LF, 1/10 dilution) for 12, 24 and $48 \mathrm{~h}$ (see also fig. 3a). Immunoreactive proteins corresponding to the short and long PRL receptor (PRL-R) isoforms are indicated. Blots are representative of 3 independent experiments. Actin served as loading control. f Western blot analysis of phosphorylated JAK2 (125 kDa) and STAT3 $(92 \mathrm{kDa})$ levels in BUVECs not treated or treated with large follicles (LF, 1/10 dilution, $12 \mathrm{~h}$ ), PRL ( $2 \mathrm{nM}, 5 \mathrm{~min}$ ), or with large follicles for $12 \mathrm{~h}$ followed by PRL for $5 \mathrm{~min}(\mathrm{n}=3)$ (see also fig. 3b). g, h Quantification of JAK2 and STAT3 phosphorylation by densitometry $(n=3) . L F=$ Large follicles. ${ }^{a} p<0.05$ versus no treatment. i Effect on BUVEC proliferation of treatment with large follicles (LF, $1 / 10$ dilution) for $48 \mathrm{~h}$, PRL for $36 \mathrm{~h}$ in the absence or presence of a 12-hour incubation with large follicles. Each experimental group was performed with or without $(+/-)$ a $15-$ min pretreatment with the JAK2 inhibitor, AG490 (100 $\mu \mathrm{M})$ (see also fig. $3 c) .{ }^{a} \mathrm{p}<0.05$ versus no treatment $(\mathrm{n}=3)$. 
tor-like proteins, suggesting that upregulation of the PRL receptors is one of the mechanisms by which the FF enables the mitogenic action of PRL on vascular endothelium. Among reported constituents of FF, sexual steroids may promote PRL receptor expression [38]. Proinflammatory cytokines have also been detected in FF [39], and they promote the expression of the long PRL receptor isoform in rat pulmonary fibroblasts [40].

In support of PRL activating its receptor in BUVECs, we show that PRL alone induces the phosphorylation of JAK2 and STAT3 in these cells. Interestingly, FF also stimulates the phosphorylation of JAK2 and STAT3, but the effects of FF and PRL are not additive. This indicates that activation of the JAK2/STAT3 pathway is associated neither with the FF-dependent upregulation of the PRL receptor nor with the ability of PRL to stimulate BUVEC proliferation. Moreover, AG490, which specifically blocks JAK2-STAT pathways in bovine aortic endothelial cells [22] and human umbilical vein endothelial cells [41] at the same dose used in the present study, did not reverse the mitogenic effects of either FF or PRL administered after priming the cells with FF, confirming that JAK2mediated pathways are not involved in the proangiogenic action of these 2 substances. While JAK2/STATs is the canonical pathway activated by PRL, there is evidence that the PRL receptor can also signal through pathways independent of JAK2 [42].
The roles of PRL in the ovary are numerous, and high levels of PRL in FF have been associated with successful pregnancy [7]. PRL receptor null females show early involution of the corpus luteum and infertility [43]. More recently, overexpression of the short form of the PRL receptor in the absence of the long receptor isoform was shown to cause severe follicular impairment that leads to premature ovarian failure, a common condition causing infertility and premature aging in $1 \%$ of women [44]. The degree to which proangiogenic proteins present in the FF influence the proliferation of endothelial cells within the follicle is unclear. However, the production and bioactivity of PRL within the follicle can be monitored by measuring its levels in FF. Because endothelial cell proliferation is an essential step of angiogenesis and the promotion of angiogenesis is a prerequisite for an adequate maturation of ovarian follicles and corpus luteum formation $[1,24]$, the possibility that the ovarian actions of PRL involve the promotion of angiogenesis deserves further investigation.

\section{Acknowledgements}

We thank G. Perera, G. Nava, F. López-Barrera, D. Mondragón, A. Prado and M. Garcia for their technical assistance and D.D. Pless for critically editing the manuscript. This work was supported by the National Council of Science and Technology of Mexico (grant 44387) and by the CONACYT grant 49292.

\section{References}

1 Abulafia O, Sherer DM: Angiogenesis of the ovary. Am J Obstet Gynecol 2000;182:240246.

2 Gospodarowicz D, Cheng J, Lui GM, Baird A, Esch F, Bohlen P: Corpus luteum angiogenic factor is related to fibroblast growth factor. Endocrinology 1985;117:2383-2391.

- 3 Hayashi KG, Acosta TJ, Tetsuka M, Berisha B, Matsui M, Schams D, Ohtani M, Miyamoto A: Involvement of angiopoietin-tie system in bovine follicular development and atresia: messenger RNA expression in theca interna and effect on steroid secretion. Biol Reprod 2003;69:2078-2084.

4 Bagavandoss P, Sage EH, Vernon RB: Secreted protein, acidic and rich in cysteine (SPARC) and thrombospondin in the developing follicle and corpus luteum of the rat. J Histochem Cytochem 1998;46:1043-1049.

-5 Fraser HM, Duncan WC: Vascular morphogenesis in the primate ovary. Angiogenesis 2005;8:101-116.
-

Clapp C, Thebault S, Martinez de la Escalera G: Role of prolactin and vasoinhibins in the regulation of vascular function in mammary gland. J Mammary Gland Biol Neoplasia 2008; 13:55-67.

$\checkmark 7$ Laufer N, Botero-Ruiz W, DeCherney AH, Haseltine F, Polan ML, Behrman HR: Gonadotropin and prolactin levels in follicular fluid of human ova successfully fertilized in vitro. J Clin Endocrinol Metab 1984;58:430434.

8 Clapp C, Aranda J, Gonzalez C, Jeziorski MC, Martinez de la Escalera G: Vasoinhibins: endogenous regulators of angiogenesis and vascular function. Trends Endocrinol Metab 2006;17:301-307.

$\checkmark$ Ueda E, Ozerdem U, Chen YH, Yao M, Huang KT, Sun H, Martins-Green M, Bartolini P, Walker AM: A molecular mimic demonstrates that phosphorylated human prolactin is a potent anti-angiogenic hormone. Endocr Relat Cancer 2006;13:95-111.
10 Gaytan F, Morales C, Bellido C, Aguilar E, Sanchez-Criado JE: Role of prolactin in the regulation of macrophages and in the proliferative activity of vascular cells in newly formed and regressing rat corpora lutea. Biol Reprod 1997;57:478-486.

11 Grosdemouge I, Bachelot A, Lucas A, Baran N, Kelly PA, Binart N: Effects of deletion of the prolactin receptor on ovarian gene expression. Reprod Biol Endocrinol 2003;1:12.

12 Struman I, Bentzien F, Lee H, Mainfroid V, D'Angelo G, Goffin V, Weiner RI, Martial JA: Opposing actions of intact and N-terminal fragments of the human prolactin/ growth hormone family members on angiogenesis: an efficient mechanism for the regulation of angiogenesis. Proc Natl Acad Sci USA 1999;96:1246-1251.

13 Ko JY, Ahn YL, Cho BN: Angiogenesis and white blood cell proliferation induced in mice by injection of a prolactin-expressing plasmid into muscle. Mol Cells 2003;15:262270. 
14 Hilfiker-Kleiner D, Kaminski K, Podewski E, Bonda T, Schaefer A, Sliwa K, Forster O, Quint A, Landmesser U, Doerries C, Luchtefeld M, Poli V, Schneider MD, Balligand JL, Desjardins F, Ansari A, Struman I, Nguyen NQ, Zschemisch NH, Klein G, Heusch G, Schulz R, Hilfiker A, Drexler H: A cathepsin $\mathrm{D}$-cleaved $16 \mathrm{kDa}$ form of prolactin mediates postpartum cardiomyopathy. Cell 2007;128: 589-600.

$\checkmark 15$ Ricken AM, Traenkner A, Merkwitz C, Hummitzsch K, Grosche J, Spanel-Borowski $\mathrm{K}$ : The short prolactin receptor predominates in endothelial cells of micro- and macrovascular origin. J Vasc Res 2007;44:19 30.

-16 Malaguarnera L, Pilastro MR, Quan S, Ghattas MH, Yang L, Mezentsev AV, Kushida T, Abraham NG, Kappas A: Significance of heme oxygenase in prolactin-mediated cell proliferation and angiogenesis in human endothelial cells. Int J Mol Med 2002;10:433440.

-17 Bole-Feysot C, Goffin V, Edery M, Binart N, Kelly PA: Prolactin (PRL) and its receptor: actions, signal transduction pathways and phenotypes observed in PRL receptor knockout mice. Endocr Rev 1998;19:225-268.

-18 Merkle CJ, Schuler LA, Schaeffer RC Jr, Gribbon JM, Montgomery DW: Structural and functional effects of high prolactin levels on injured endothelial cells: evidence for an endothelial prolactin receptor. Endocrine 2000;13:37-46.

-19 Cruz J, Avina-Zubieta A, Martinez de la Escalera G, Clapp C, Lavalle C: Molecular heterogeneity of prolactin in the plasma of patients with systemic lupus erythematosus. Arthritis Rheum 2001;44:1331-1335.

-20 Duenas Z, Torner L, Corbacho AM, Ochoa A, Gutierrez-Ospina G, Lopez-Barrera F, Barrios FA, Berger P, Martinez de la Escalera G, Clapp C: Inhibition of rat corneal angiogenesis by $16-\mathrm{kDa}$ prolactin and by endogenous prolactin-like molecules. Invest Ophthalmol Vis Sci 1999;40:2498-2505.

-21 Cajero-Juarez M, Avila B, Ochoa A, GarridoGuerrero E, Varela-Echavarria A, Martinez de la Escalera G, Clapp C: Immortalization of bovine umbilical vein endothelial cells: a model for the study of vascular endothelium. Eur J Cell Biol 2002;81:1-8.

-22 Neria F, Caramelo C, Peinado H, GonzalezPacheco FR, Deudero JJ, de Solis AJ, Fernandez-Sanchez R, Penate S, Cano A, Castilla MA: Mechanisms of endothelial cell protection by blockade of the JAK2 pathway. Am J Physiol Cell Physiol 2007;292:C1123-C1131.
23 Carley WW, Niedbala MJ, Gerritsen ME: Isolation, cultivation, and partial characterization of microvascular endothelium derived from human lung. Am J Respir Cell Mol Biol 1992;7:620-630.

24 Tamanini C, De Ambrogi M: Angiogenesis in developing follicle and corpus luteum. Reprod Domest Anim 2004;39:206-216.

25 Gruemmer R, Klein-Hitpass L, Neulen J: Regulation of gene expression in endothelial cells: the role of human follicular fluid. J Mol Endocrinol 2005;34:37-46.

26 Risau W: Mechanisms of angiogenesis. Nature 1997;386:671-674.

27 Przala J, Grazul A, Wiesak T, Muszynska A, Dusza L: Steroid hormones and prolactin in porcine follicular fluid in estrous cycle and early pregnancy. Exp Clin Endocrinol 1985; 86:291-296.

28 Henderson KM, McNeilly AS, Swanston IA: Gonadotrophin and steroid concentrations in bovine follicular fluid and their relationship to follicle size. J Reprod Fertil 1982;65: 467-473.

29 Phelps JY, Bugg EM, Shamblott MJ, Vlahos NP, Whelan J, Zacur HA: Prolactin gene expression in human ovarian follicular cells. Fertil Steril 2003;79:182-185.

30 Dunaif AE, Zimmerman EA, Friesen HG, Frantz AG: Intracellular localization of prolactin receptor and prolactin in the rat ovary by immunocytochemistry. Endocrinology 1982;110:1465-1471.

31 Wise T, Maurer RR: Follicular development, oocyte viability and recovery in relation to follicular steroids, prolactin and glycosaminoglycans throughout the estrous period in superovulated heifers with a normal LH surge, no detectable LH surge, and progestin inhibition of LH surge. Domest Anim Endocrinol 1994;11:35-58.

32 Bohnet HG, Baukloh V: Prolactin concentrations in follicular fluid following ovarian hyperstimulation for in vitro fertilization. Horm Res 1985;22:189-195

-33 Lindner C, Lichtenberg V, Westhof G, Braendle W, Bettendorf G: Endocrine parameters of human follicular fluid and fertilization capacity of oocytes. Horm Metab Res 1988;20:243-246.

34 Fraser HM, Lunn SF: Angiogenesis and its control in the female reproductive system. $\mathrm{Br}$ Med Bull 2000;56:787-797.
35 von Otte S, Paletta JR, Becker S, Konig S, Fobker M, Greb RR, Kiesel L, Assmann G, Diedrich K, Nofer JR: Follicular fluid high density lipoprotein-associated sphingosine 1-phosphate is a novel mediator of ovarian angiogenesis. J Biol Chem 2006;281:53985405.

-36 Dawson DW, Volpert OV, Gillis P, Crawford SE, Xu H, Benedict W, Bouck NP: Pigment epithelium-derived factor: a potent inhibitor of angiogenesis. Science 1999;285:245-248.

-37 Aranda J, Rivera JC, Jeziorski MC, RiesgoEscovar J, Nava G, Lopez-Barrera F, QuirozMercado H, Berger P, Martinez de la Escalera G, Clapp C: Prolactins are natural inhibitors of angiogenesis in the retina. Invest Ophthalmol Vis Sci 2005;46:2947-2953.

38 Tseng L, Zhu HH: Progestin, estrogen, and insulin-like growth factor-I stimulate the prolactin receptor mRNA in human endometrial stromal cells. J Soc Gynecol Investig 1998;5:149-155.

39 Buscher U, Chen FC, Kentenich H, Schmiady $\mathrm{H}$ : Cytokines in the follicular fluid of stimulated and non-stimulated human ovaries; is ovulation a suppressed inflammatory reaction? Hum Reprod 1999;14:162-166.

40 Corbacho AM, Macotela Y, Nava G, Eiserich JP, Cross CE, Martinez de la Escalera G, Clapp C: Cytokine induction of prolactin receptors mediates prolactin inhibition of nitric oxide synthesis in pulmonary fibroblasts. FEBS Lett 2003;544:171-175.

41 Matsumiya T, Imaizumi T, Itaya H, Shibata T, Yoshida H, Sakaki H, Kimura H, Satoh $\mathrm{K}$ : Production of growth related oncogene protein-alpha in human umbilical vein endothelial cells stimulated with soluble interleukin- 6 receptor-alpha: role of signal transducers, janus kinase 2 and mitogen-activated kinase kinase. Life Sci 2002;70:3179-3190.

42 Kochendoerfer SK, Krishnan N, Buckley DJ, Buckley AR: Prolactin regulation of $\mathrm{Bcl}-2$ family members: increased expression of bcl-xL but not mcl-1 or bad in Nb2-T cells. J Endocrinol 2003;178:265-273.

43 Stocco C, Telleria C, Gibori G: The molecular control of corpus luteum formation, function, and regression. Endocr Rev 2007; 28:117-149.

44 Halperin J, Devi SY, Elizur S, Stocco C, Shehu A, Rebourcet D, Unterman TG, Leslie ND, Le J, Binart N, Gibori G: Prolactin signaling through the short form of its receptor represses forkhead transcription factor FOXO3 and its target gene galt causing a severe ovarian defect. Mol Endocrinol 2008; 22:513-522. 